\title{
Prevalence of risk factors for noncommunicable diseases in adults: key findings from the Pakistan STEPS survey
}

Ibrar Rafique ${ }^{1}$, Muhammad A.N. Saqib ${ }^{1}$, Muhammad A. Munir ${ }^{1}$, Huma Qureshi $^{1}$, Rizwanullah ${ }^{1}$, Shahzad A. Khan² and Heba Fouad ${ }^{3}$

${ }^{1}$ Pakistan Health Research Council, Islamabad, Pakistan (Correspondence to: Muhammad A.N. Saqib: arif289@gmail.com). ${ }^{2}$ World Health Organization, Pakistan Country Office, Islamabad, Pakistan. ${ }^{3}$ World Health Organization, Regional Office for the Eastern Mediterranean, Cairo, Egypt.

Background: Pakistan lacks data on the prevalence of risk factors for common noncommunicable diseases (NCDs).

Objectives: This study aimed to determine the prevalence of risk factors for NCDs among a population-based sample in Punjab and Sindh provinces, Pakistan.

Methods: This study was conducted in 2013-2014. The NCD risk factors examined were: current daily smoking, eating fewer than 5 servings of fruits/vegetable a day, low physical activity, overweight and obesity. A total of 7710 households were selected and 1 adult was enrolled from each household. Data were collected using the WHO STEPS instrument (Step 1 and 2), and analysed according to the STEPS statistical plan.

Results: The prevalence of tobacco use was $19.7 \%$. The majority of the respondents (96.5\%) consumed fewer than 5 servings of fruits/vegetables a day, $41.5 \%$ had a low level of physical activity, $26.3 \%$ were overweight and $14.9 \%$ were obese. The prevalence of stage I and stage II hypertension, including those on medication, was $37 \%$ and $15.9 \%$ respectively. The prevalence of NCD risk factors differed significantly by sex and occupation $(P=0.0001)$ but not by age group $(P=0.118)$, level of education $(P=0.668)$ and province $(P=0.056)$. Only $0.6 \%$ of the sample had none of the 5 NCD risk factors while $40 \%$ had 3-5.

Conclusion: The high prevalence of NCD risk factors in Punjab and Sindh provinces is of concern. Urgent public health interventions are needed to reduce them, especially in youth and young adults.

Keywords: Hypertension, noncommunicable diseases, Pakistan, physical activity, tobacco use

Citation: Rafique I, Saqib MAN, Munir MA, Qureshi H, Rizwanullah, Khan SA, et al. Prevalence of risk factors for noncommunicable diseases in adults: key findings from the Pakistan STEPS survey. East Mediterr Health J. 2018;24(1):33-41. https://doi.org/10.26719/2018.24.1.33

Received: 28/06/17; accepted: 21/11/17

Copyright (c) World Health Organization (WHO) 2018. Some rights reserved. This work is available under the CC BY-NC-SA 3.o IGO license (https:// creativecommons.org/licenses/by-nc-sa/3.o/igo)

\section{Introduction}

Noncommunicable diseases (NCDs) include diabetes, hypertension, cancers, mental health disorders, arthritis, injuries and accidents $(1,2)$. In Pakistan, NCDs are among the top 10 causes of morbidity and mortality, and it is estimated that NCDs and injuries cause $77 \%$ of agestandardized deaths (3). Diabetes, hypertension, cancers and other NCDs are common in Pakistan. According to a diabetes survey in 1994, the prevalence of diabetes in the general population was $11 \%(4,5)$, and the National Health Survey of Pakistan (NHSP) 1990-94 reported that 24\% of urban and $13 \%$ of rural populations had diabetes (6). Similarly, the prevalence of pre-diabetes, hypertension and diabetes in the general population of Karachi was reported as $40 \%, 18 \%$ and $8 \%$ respectively ( 7 ).

Previous studies have reported the prevalence of common NCD risk factors in Pakistan. According to the NHSP, tobacco consumption was $34 \%$ in men and $12.5 \%$ in women, $24 \%$ and $14 \%$ of the urban and rural populations, respectively, were overweight, and $17.9 \%$ of the rural population had hypertension (6). A recent study in Karachi showed that $53 \%$ of the population had abdominal obesity and $45 \%$ were tobacco users (7). It is estimated that by $2025,3.87$ million premature deaths caused by NCDs will occur in Pakistan, with serious economic consequences (8).

Since the NHSP, no national survey on the prevalence of NCDs and their risk factors has been conducted in Pakistan. The STEPS survey 2013-2014 was conducted to determine the prevalence and magnitude of common NCD risk factors in 2 large provinces of Pakistan - Punjab and Sindh. This paper describes the key finding of this survey and compares the findings with local, regional and international data.

\section{Methods}

\section{Survey instrument}

The STEPS survey was conducted from November 2013 to April 2014. Data were collected on NCD risk factors using World Health Organization (WHO) STEP 1 and 2 instruments of the standard STEPS methodology (9). The NCD risk factors included in the study were: tobacco use, physical inactivity, unhealthy diet, overweight/obesity and raised blood pressure (10-12).

\section{Target population and sample size}

The target population was all men and women aged 18 years or above living in Punjab and Sindh; this covers 
almost $75 \%$ of the total population of Pakistan. A sample size of 7710 individuals (Punjab 4110, Sindh 3600, proportionate to population size of the province) was calculated assuming 95\% precision and 5\% non-response with representation of urban/rural residents and males/ females based on their distribution in the province.

\section{Sampling}

A 2-stage stratified sampling approach was used in which the division (the largest administrative unit of provinces, which is followed by districts, tehsils/talukas and union councils) was selected as primary sampling units and union councils were selected as secondary sampling units. All 13 divisions of both provinces were selected, while the union councils were selected based on probability proportionate to size with the population in each union council being the measure of size. A total of 257 union councils ( 137 from Punjab and 120 from Sindh) were selected randomly from both rural and urban union councils. Of the selected union councils, 110 were urban (57 Punjab and 53 Sindh) and 147 were rural (80 Punjab and 67 Sindh). In each urban union council, sample blocks of approximately 2000 people were formed using a quick count and of these, 1 block was picked randomly. From the selected block, a cluster of 150 households was counted and 30 households were selected by taking every fifth household. In rural union councils (average 4-5 villages in each union council), 1 village was selected randomly. A cluster of 150 households was marked from which 30 households were selected by taking every fifth household.

From each selected household, names and ages of all members (male/female) who were 18 years or more were entered in a personnel digital assistant which then randomly selected 1 individual using the Kish method (13).

\section{Data collection}

Data were collected using the standard STEPS 1 and 2 instruments; all core and expanded modules of STEPS 1 were included while for STEP 2, only core modules were used. In addition, the optional modules of tobacco policy and injury were also included (14). The questionnaire was adapted to local needs, translated into Urdu, the national language, and back-translated into English for verification. After pilot-testing and making further refinements, the Urdu version of the questionnaire was uploaded on the personnel digital assistant. The consent form and report forms were also translated into Urdu. For clarity, show cards and charts were used as described in the country report (15).

Data collection teams comprised an enumerator, interviewers (male and female) and a supervisor who were trained on the questionnaire and physical measurements. Each team visited the assigned union councils and followed the household and individual selection criteria as described above. The selected individual was interviewed and their height $(\mathrm{cm})$, weight $(\mathrm{kg})$, waist circumference $(\mathrm{cm})$ and blood pressure (BP) (systolic and diastolic) were measured. Height and weight were measured using SECA stadiometer 213 (SECA,
Germany) and SECA 874 weighing machines (SECA, Germany) respectively, and body mass index (BMI) was calculated. Waist circumference was measured at the umbilicus level using a measuring tape. Blood pressure was measured in sitting position using BOSO digital apparatus (BOSO, Germany). Three readings were taken and their average was used. For female participants, both interview and measurements were done by the female interviewer.

\section{Ethical considerations}

Ethical clearance for the survey was given by the National Bioethics Committee, Pakistan. Provincial health directorates were informed prior to the survey. Written informed consent was taken from all participants. For participants who could not read, the interviewer read the consent form to them and took their consent.

\section{Data analysis}

All data were transferred from the personnel digital assistant to the computer and converted into an Excel sheet which was checked, cleaned and transferred to Epi Info, 3.5.1. Data were analysed using the WHO STEPS statistical plan. Standard WHO definitions were used to define low physical activity (< 150 minutes of moderateintensity activity per week, or equivalent), adequate fruit and vegetable consumption (5 servings of fruit and/ or vegetables on average per day), overweight (BMI = $\left.25-29 \mathrm{~kg} / \mathrm{m}^{2}\right)$, obesity $\left(\right.$ BMI $\left.\geq 30 \mathrm{~kg} / \mathrm{m}^{2}\right)$ and raised blood pressure (systolic blood pressure $\geq 140$ and/or diastolic blood pressure $\geq 90 \mathrm{mmHg}$, or currently on medication for raised blood pressure) (16). Sampling weights were developed based on selection probabilities at 2 stages of sampling for selection of the union councils and households in the survey. The first stage selection was based on the measure of size, i.e. population in each union council in the sampling frame, and the second stage was based on the total number of households in the sample union council. The product of the inverse of probabilities at both stages was the sampling weight. The overall response rate was calculated from household response rate and personal level response rate.

The chi-squared test was used to determine the association between the prevalence of NCD risk factors (current daily smoking, consumption of fewer than 5 servings of fruits/vegetable a day, low physical activity, overweight and obesity) and demographic characteristics and province. A $P$-value $<0.05$ was considered statistically significant. For clustering of individuals with risk factors, the number of risk factors $(0-5)$ were analysed. The data were categorized into people with no risk factors, 1-2 risk factors and 3-5 risk factors. The magnitude of the burden of NCD risk factors was calculated by estimating the actual burden among the total population of Pakistan according to recent census data of Pakistan 2017 (17).

\section{Results}

A total of 7366 individuals were enrolled. Overall response rate was $95.5 \%$, which was $96.8 \%$ in Punjab 
and $93.6 \%$ in Sindh. The demographic characteristics of study participants are given in Table 1 . The majority of the participants were women (57.2\%). About 40\% had no formal education or had not completed primary school and $62.8 \%$ were unpaid (housewives, students, retirees and unemployed people).

Table 2 shows NCD risk factors according to socioeconomic characteristics. The overall prevalence of tobacco use was $19.7 \%$ (95\% CI: 18.0-21.3\%); 13.9\% (95\% CI: 12.4-15.3\%) smoked tobacco and 6.9\% (95\% CI: $5.7-8.0 \%$ ) used smokeless tobacco. Among men, 27.8\% smoked tobacco and $9.9 \%$ used smokeless tobacco; among women, $4.2 \%$ smoked tobacco and $4.7 \%$ used smokeless tobacco. Figure 1 shows the types of smoking and smokeless tobacco products used. Most tobacco smokers used cigarettes (68\%), followed by cigars $(29 \%)$. As regards smokeless tobacco, $60 \%$ used snuff by mouth and $23 \%$ chewed tobacco.

Among smokers, 91.4\% (95\% CI: 89.2-93.6\%) were daily smokers and the mean age at starting smoking was 22.1 years. The prevalence of exposure to second-hand smoke at home and in the workplace was $27.3 \%$ (95\% CI: $25.6-28.9 \%$ ) and $16.5 \%$ (95\% CI: $14.8-18.1 \%$ ) respectively. Men were more exposed to second-hand smoke in the workplace, $30.7 \%$ (95\% CI: $27.4-34.0 \%$ ) compared with $7.2 \%$ (95\% CI: $5.7-8.7 \%$ ) for women.

Of the total sample, $14.9 \%$ (95\% CI: $13.4-16.5 \%$ ) were obese and $26.3 \%$ (95\% CI: $24.8-27.8 \%$ ) were overweight (Table 2); $11.3 \%$ (95\% CI: 10.0-12.7\%) were underweight $\left(\mathrm{BMI}<18.5 \mathrm{~kg} / \mathrm{m}^{2}\right)$. The prevalence of low fruit/vegetable consumption $(<5$ portions a day) and low physical activity $(<150$ minutes of moderate-intensity activity

\begin{tabular}{ll}
\hline Table 1 Sociodemographic characteristics of participants \\
\hline Characteristic & $\%(\mathbf{n}=\mathbf{7 3 6 6})$ \\
\hline Sex & \\
Male & 42.8 \\
Female & 57.2 \\
Overall & \\
\hline Age group (years) & \\
\hline 18-29 & 36.0 \\
30-44 & 36.8 \\
45-59 & 18.7 \\
60-69 & 8.5 \\
\hline Education & \\
\hline No formal schooling & 34.2 \\
Some primary schooling & 6.0 \\
Primary school completed & 14.1 \\
Secondary school completed & 11.4 \\
High school completed & 19.0 \\
College/university completed & 9.4 \\
Postgraduate degree & 6.1 \\
\hline Marital status & \\
\hline Currently married & 80.4 \\
Never married & 15.8 \\
Other (separated, divorced, widowed) & 3.8 \\
\hline Employment & \\
\hline Government employee & 62.8 \\
Nongovernment employee & \\
Self-employed & \\
Unpaid & \\
\hline & \\
\hline
\end{tabular}

${ }^{a}$ Housewives, students, retirees and unemployed people.

\begin{tabular}{|c|c|c|c|c|c|c|}
\hline \multirow[t]{2}{*}{ Characteristic } & Tobacco use & $\begin{array}{l}<5 \text { servings of } \\
\text { fruits/vegetable } \\
\text { a day }\end{array}$ & $\begin{array}{l}\text { Low level of } \\
\text { physical activity }\end{array}$ & Overweight & Obese & P-value \\
\hline & $\%(95 \% \mathrm{CI})$ & $\%(95 \% \mathrm{CI})$ & $\%(95 \% \mathrm{CI})$ & $\%(95 \% \mathrm{CI})$ & $\%(95 \% \mathrm{CI})$ & \\
\hline Overall & $19.7(18.0-21.3)$ & $96.5(95.7-97.2)$ & $46.1(43.3-48.9)$ & $26.3(24.8-27.8)$ & $14.9(13.4-16.5)$ & \\
\hline Province & & & & & & 0.056 \\
\hline Punjab & $17.6(15.6-19.7)$ & $96.9(96.1-97.6)$ & $53.2(50.0-56.5)$ & $28.2(26.3-30.1)$ & $16.8(14.7-18.8)$ & \\
\hline Sindh & $25.0(22.5-27.6)$ & $94.4(92.7-96.1)$ & $27.2(23.6-30.8)$ & $21.3(19.3-23.3)$ & $10.3(8.4-12.3)$ & \\
\hline Sex & & & & & & 0.0001 \\
\hline Male & $35.6(32.9-38.4)$ & $95.2(94.0-96.3)$ & $28.2(25.2-31.3)$ & $26.5(24.3-28.8)$ & $12.1(10.2-14.0)$ & \\
\hline Female & $8.7(7.0-10.3)$ & $97.4(96.7-98.0)$ & $58.6(55.4-61.8)$ & $26.2(24.3-28.0)$ & $17.1(15.0-19.1)$ & \\
\hline Age group (years) & & & & & & 0.118 \\
\hline $18-29$ & $10.9(9.2-12.6)$ & $96.0(95.0-97.0)$ & $47.0(43.7-50.4$ & $19.1(16.9-21.2$ & $8.6(7.1-10.1)$ & \\
\hline $30-44$ & $19.2(16.9-21.5)$ & $96.3(95.4-97.3)$ & $43.6(40.1-47.2)$ & $31.3(28.9-33.6)$ & $14.9(13.1-16.7)$ & \\
\hline $45-59$ & $29.6(26.2-32.9)$ & $97.0(95.9-98.0)$ & $44.6(40.6-48.6)$ & $30.8(27.5-34.1)$ & $18.1(15.2-21.0)$ & \\
\hline $60-69$ & $33.9(29.3-38.5)$ & $97.6(96.4-98.8)$ & $55.7(49.6-61.9)$ & $23.2(18.8-27.5)$ & $15.3(11.6-18.9)$ & \\
\hline Education & & & & & & 0.668 \\
\hline No formal schooling & $24.8(22.3-27.2)$ & $97.5(96.7-98.2)$ & $40.6(37.1-44.1)$ & $24.0(21.9-26.1)$ & $11.7(9.8-13.5)$ & \\
\hline $\begin{array}{l}\text { Primary school } \\
\text { completed }\end{array}$ & $19.2(16.0-22.5)$ & $96.1(94.3-97.9)$ & $47.0(42.5-51.5)$ & $26.4(22.5-30.4)$ & $15.8(12.4-19.3)$ & \\
\hline
\end{tabular}


Table 2 Prevalence of noncommunicable disease risk factors by province and sociodemographic characteristics of the respondents (concluded)

\begin{tabular}{|c|c|c|c|c|c|c|}
\hline Characteristic & Tobacco use & $\begin{array}{l}<5 \text { servings of } \\
\text { fruits/vegetable } \\
\text { a day }\end{array}$ & $\begin{array}{l}\text { Low level of } \\
\text { physical activity }\end{array}$ & Overweight & Obese & P-value \\
\hline & $\%(95 \% \mathrm{CI})$ & $\%(95 \% \mathrm{CI})$ & $\%(95 \% \mathrm{CI})$ & $\%(95 \% \mathrm{CI})$ & $\%(95 \% \mathrm{CI})$ & \\
\hline Overall & $19.7(18.0-21.3)$ & $96.5(95.7-97.2)$ & $46.1(43.3-48.9)$ & $26.3(24.8-27.8)$ & $14.9(13.4-16.5)$ & \\
\hline $\begin{array}{l}\text { Secondary school } \\
\text { completed }\end{array}$ & $16.4(13.3-19.5)$ & $95.6(93.5-97.6)$ & $48.8(43.2-54.5)$ & $27.8(23.6-32.0)$ & $19.0(15.2-22.9)$ & \\
\hline $\begin{array}{l}\text { College/university } \\
\text { completed }\end{array}$ & $10.9(7.9-13.9)$ & $94.1(91.9-96.2)$ & $52.5(46.5-58.6)$ & $25.7(21.0-30.4)$ & $18.4(13.9-22.9)$ & \\
\hline Postgraduate degree & $11.8(7.8-15.7)$ & $91.7(88.4-95.0)$ & $52.8(45.3-60.3)$ & $30.7(24.5-37.0)$ & $20.2(14.1-26.2)$ & \\
\hline Employment & & & & & & 0.0001 \\
\hline Government employee & $20.1(14.4-25.8)$ & $95.4(92.8-98.1)$ & $32.0(25.2-38.8)$ & $31.9(24.8-39.0)$ & $21.3(15.1-27.5)$ & \\
\hline $\begin{array}{l}\text { Nongovernment } \\
\text { employee }\end{array}$ & $36.9(33.5-40.3)$ & $96.4(95.2-97.5)$ & $26.1(22.3-29.8)$ & $25.2(22.0-28.5)$ & $9.6(7.5-11.7)$ & \\
\hline Self-employed & $31.3(27.2-35.5)$ & $93.2(91.1-95.3)$ & $30.9(25.7-36.0)$ & $30.5(26.2-34.8)$ & $15.9(12.4-19.5)$ & \\
\hline Unpaid $^{\text {a }}$ & $12.5(10.9-14.2)$ & $96.7(96.0-97.5)$ & $55.3(52.1-58.5)$ & $25.6(23.9-27.4)$ & $16.0(14.1-18.0)$ & \\
\hline
\end{tabular}

${ }^{a}$ Housewives, students, retirees and unemployed people.

$C I=$ confidence interval.

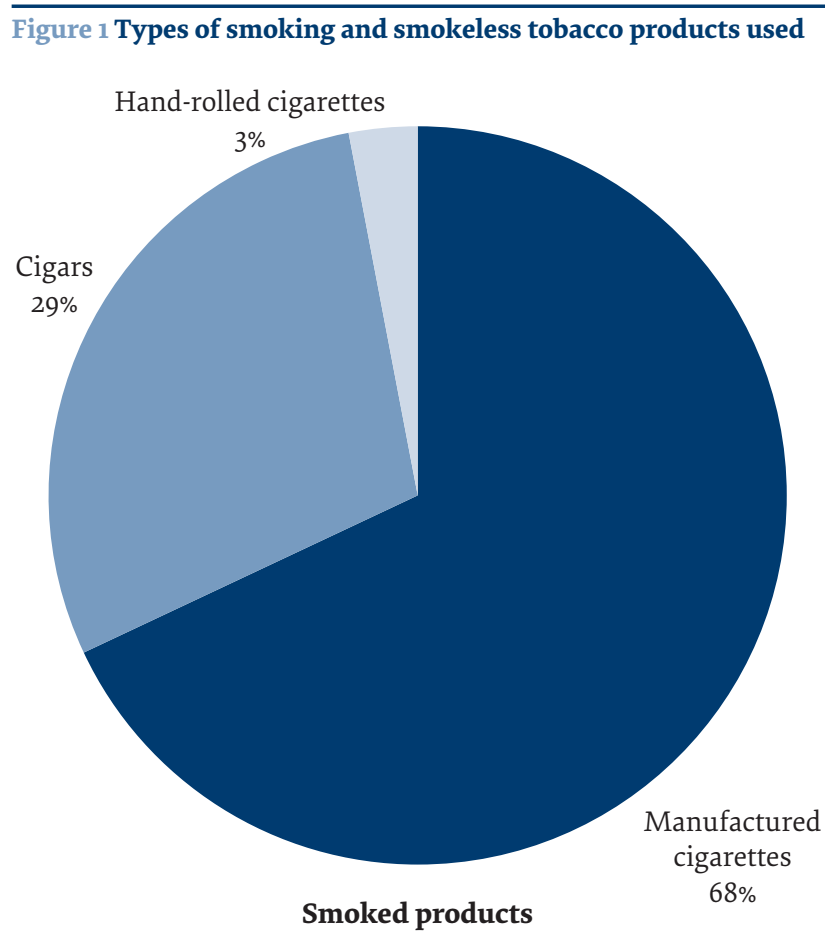

per week) were 96.5\% (95\% CI: 95.7-97.2\%) and 46.1\% (95\% CI: 43.3-48.9\%) respectively. Low physical activity and obesity were more prevalent in women, 58.6\% (95\% CI: 55.4-61.8\%) and $17.1 \%$ (95\%: CI 15.0-19.1\%) respectively than men, $28.2 \%$ (95\% CI: $25.2-31.3 \%$ ) and $12.1 \%$ (95\% CI: $10.2-14.0 \%$ ) respectively. The prevalence of low physical activity was much higher in the unpaid category - 55.3\% (95\% CI: 52.1-58.5\%) - than other occupation categories. Significant differences in the prevalence of NCD risk factors were seen between men and women $(P=0.0001)$ and the different occupations $(P=0.0001)$. No significant differences were seen between the provinces $(P=0.056)$, age groups $(P=0.11)$ and educational level $(P=0.6)$.

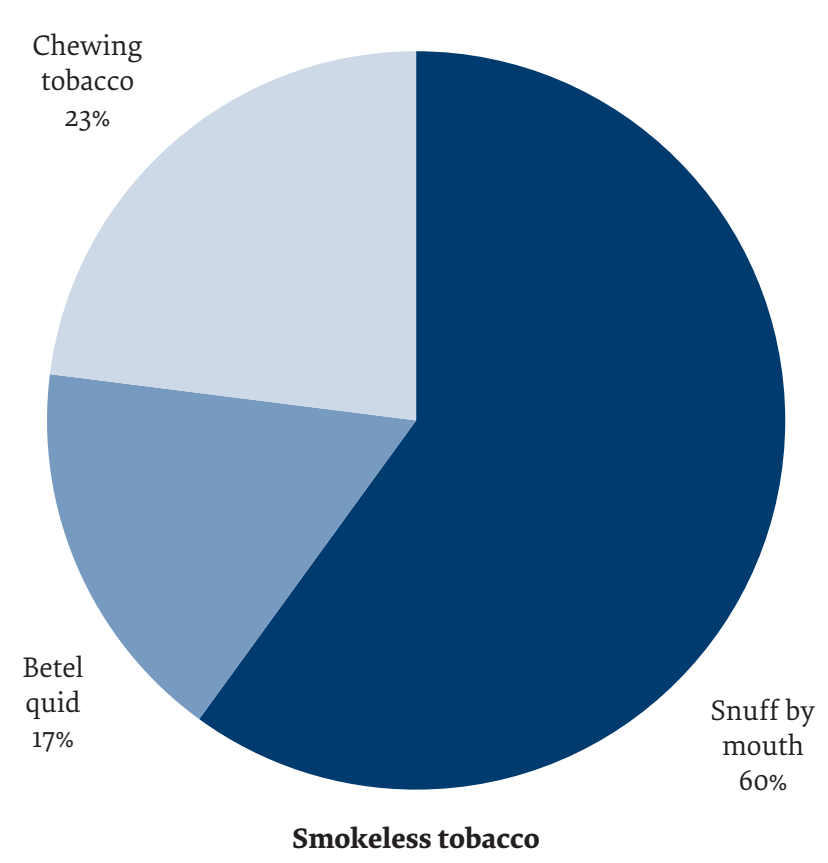

One third of the participants had been advised by their doctors to eat fruits or vegetables, and reduce salt and fat in their diet. Similarly, a quarter had been advised to quit tobacco, exercise and maintain a healthy body weight. Based on self reports, $2.7 \%$ (95\% CI: $2.1-3.2 \%$ ) and 1.0\% (95\% CI: $0.7-1.3 \%$ ) had been diagnosed with diabetes and high cholesterol levels respectively in past 12 months. Similarly, 6.3\% (95\% CI: 5.3-7.3\%) reported experiencing chest pain from heart disease or stroke in the past 12 months.

Table 3 shows the prevalence of stages I and II hypertension (including and excluding those on medication) by province, sex and age group. Stage I 


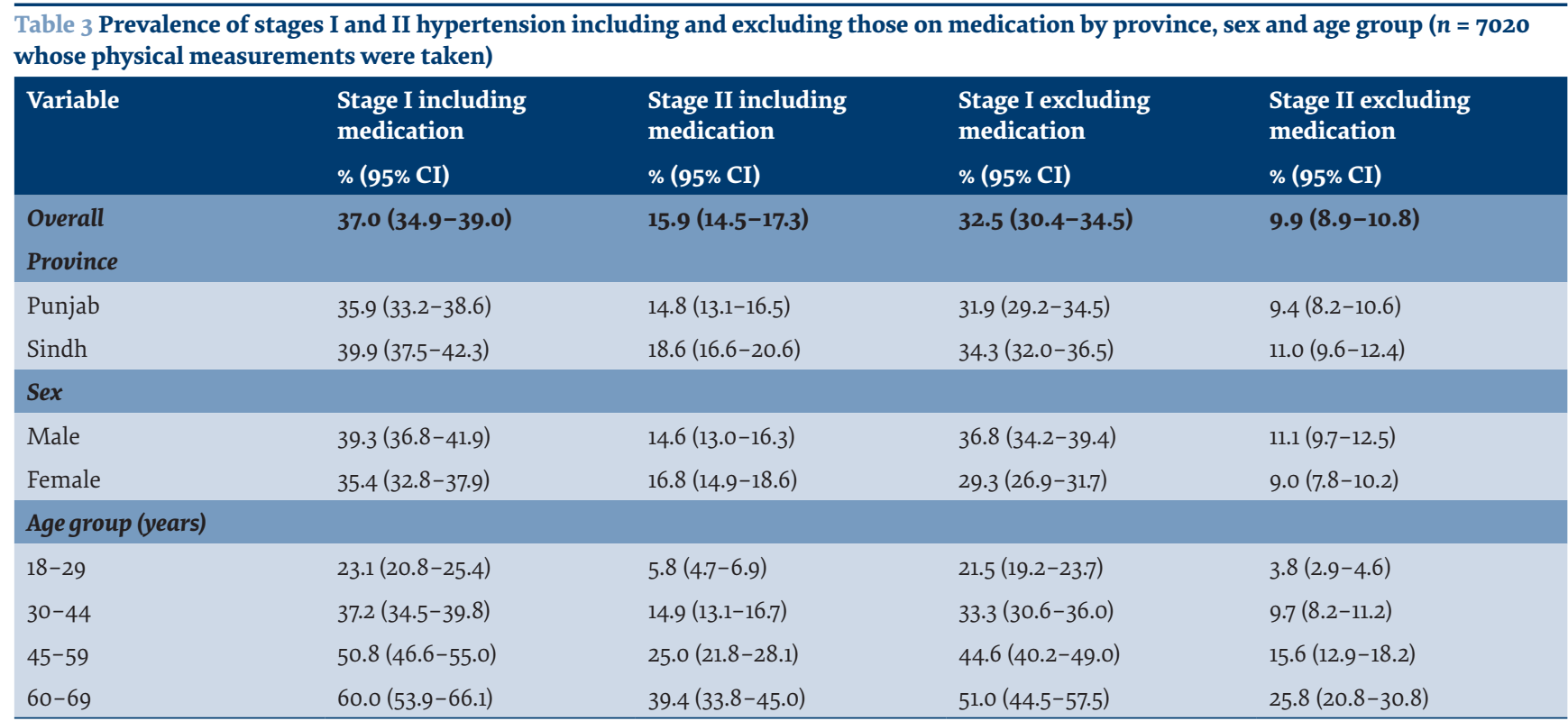

Stage I: systolic blood pressure > $140 \mathrm{mmHg}$ and diastolic blood pressure > $90 \mathrm{mmHg}$; stage II: systolic blood pressure > $160 \mathrm{mmHg}$ and diastolic blood pressure > $100 \mathrm{mmHg}$. $\mathrm{CI}=$ confidence interval.

\begin{tabular}{|c|c|c|c|c|}
\hline Variable & $\begin{array}{l}\text { No risk factors } \\
\%(95 \% \mathrm{CI})\end{array}$ & $\begin{array}{l}\text { 1-2 risk factors } \\
\%(95 \% \mathrm{CI})\end{array}$ & $\begin{array}{l}\text { 3-5 risk factors } \\
\%(95 \% \mathrm{CI})\end{array}$ & $\chi^{2}$ (P-value) \\
\hline Overall & $0.6(0.4-0.9)$ & $59.3(57.0-61.7)$ & $40.0(37.6-42.4)$ & \\
\hline Sex & & & & $0.447(0.800)$ \\
\hline Male & $1.1(0.6-1.6)$ & $61.7(59.0-64.3)$ & $37.2(34.6-39.9)$ & \\
\hline Female & $0.3(0.1-0.4)$ & $57.6(54.6-60.6)$ & $42.1(39.1-45.1)$ & \\
\hline Age groups (years) & & & & $7.792(0.020)$ \\
\hline $18-44$ & $0.8(0.5-1.1)$ & $64.9(62.4-67.5)$ & $34.3(31.7-36.8)$ & \\
\hline $45-69$ & $0.3(0.1-0.6)$ & $45.8(42.1-49.5)$ & $53.9(50.2-57.6)$ & \\
\hline
\end{tabular}

CI $=$ confidence interval.

\begin{tabular}{|c|c|c|c|}
\hline NCD risk factor & Total & Males & Females \\
\hline Population ${ }^{\mathrm{a}}$ & 104.680 million & 53.596 million & 51.083 million \\
\hline Tobacco use & 19.7\% (20.6 million) & $35.6 \%$ (19.1 million) & $8.7 \%$ (4.4 million) \\
\hline Low fruit/vegetable consumption & $96.5 \%$ (101.o million) & $95.2 \%$ (51.0 million) & $97.4 \%$ (49.8 million) \\
\hline Low level of physical activity & $46.1 \%$ (48.2 million) & $28.2 \%$ (15.1 million) & 58. $6 \%$ (29.9 million) \\
\hline Overweight & $26.3 \%$ (27.5 million) & $26.5 \%$ (14.2 million) & $26.2 \%$ (13.4 million) \\
\hline Obese & $14.9 \%$ (15.6 million) & $12.1 \%$ (6.5 million) & $17.1 \%$ (8.7 million) \\
\hline
\end{tabular}

aPopulation of people aged $\geq 18$ years.

$\mathrm{NCD}=$ noncommunicable disease.

was defined as systolic blood pressure $\geq 140 \mathrm{mmHg}$ and diastolic blood pressure $\geq 90 \mathrm{mmHg}$. Stage II was defined as systolic blood pressure $\geq 160 \mathrm{mmHg}$ and diastolic blood pressure $\geq 100 \mathrm{mmHg}$. The use of medications was self-reported. The overall prevalence of stage I and II hypertension was $37.0 \%$ (95\% CI: $34.9-39.0 \%$ ) and $15.9 \%$ (95\% CI: $14.5-17.3 \%$ ) respectively including those who were currently on medication.

Table 4 shows the combined risk factors for NCDs according to sex and age group. Only $0.6 \%$ of the participants had none of the risk factors; $40 \%$ had 3-5 and $59.3 \%$ had 1-2 risk factors which differed significantly according to age group $(P=0.02)$.

The magnitude of the burden of NCD risk factors in Pakistan is shown in Table 5. A prevalence of $96.5 \%$ with low fruits/vegetable consumption represents 101.01 million Pakistanis, while $46.1 \%$ with a low level of physical activity equates to 48.2 million of the population, 
Figure 2 Level of and time spent on physical activity by sex

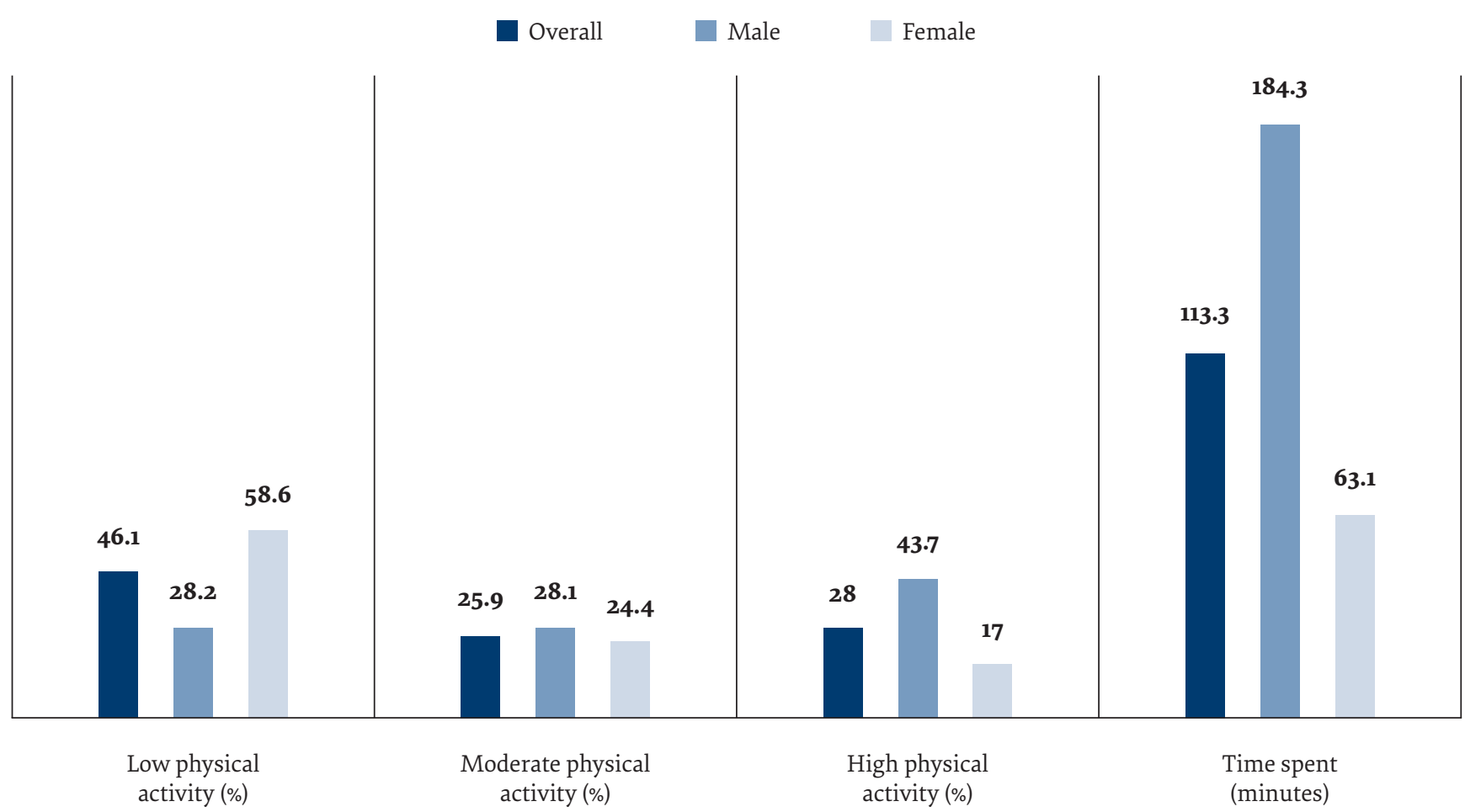

and $26.3 \%$ overweight represents 27.5 million of the population.

\section{Discussion}

This was the first national NCD survey for Pakistan which was done in 2 large provinces (Punjab and Sindh) using WHO STEPwise methodology. Key findings were high tobacco consumption, low physical activity and low consumption of vegetables and fruits. Similarly, the majority of the participants were either overweight or obese. The magnitude of the burden of NCDs showed that millions of people in Pakistan have NCD risk factors. Only $0.6 \%$ of our sample had none of the 5 main risk factors. Stage I hypertension was $37 \%$ while stage II hypertension was $15.9 \%$

\section{Tobacco use}

Almost one fifth of the population (19.7\%) used tobacco, which is similar to the $19.1 \%$ reported for people 18 years and above in Pakistan in the recent Global Adult Tobacco Survey (GATS) (18-20). The consistency in the results of both surveys may be due the same period of data collection, i.e. 2014. Another survey on tobacco use in youth (Global Youth Tobacco Survey) among 13-15-yearolds reported tobacco use in $10.7 \%$ of school students (13.3\% for boys and 6.6\% for girls) (21). The use of smokeless tobacco was $6.9 \%$ in our STEPS survey while it was $7.7 \%$ in the GATS $(19,20)$. This difference might be due to the fact that the GATS sample was drawn from 2 different provinces - Khyber Pakhtunkhwa and Baluchistan - and the use of smokeless tobacco such as naswar was high in Khyber Pakhtunkhwa. In young people, smokeless tobacco consumption was slightly lower than adults (21).
Tobacco smoking was lower in Pakistan than some nearby countries: 31\% in Nepal (22), 44\% in Bangladesh (23) and $30 \%$ in Myanmar (24). A possible reason for this may be that the prevalence of tobacco in Pakistan is reported to be decreasing as a result of various steps taken by the government (19).

\section{Low physical activity}

The prevalence of low physical activity was high in our survey, $46 \%$, compared with global population estimate of $23 \%$ reported in the global NCD report (Figure 2) (25). Compared with nearby countries, low physical activity was more prevalent in Pakistan than Sri Lanka (25\%) (26), Bangladesh (38.6\%) (23) and India (42\%) (27). The high prevalence of low physical activity might be due to an increase in urbanization in the country and changing lifestyles which may differ between countries. People are switching to more indoor activities such as playing games on mobile phones and the computer, and watching television. There is a need to create awareness among the community about the benefits of physical activity. It is possible that the questions asked about different types of physical activity do not truly describe the situation in urban and rural areas where, for example, people may be engaged in carrying or lifting heavy loads, and digging or construction work. Generally these activities (work) are carried out by people living in or coming from rural areas compared with urban areas.

\section{Fruit and vegetable consumption}

In the present study, $96.5 \%$ of our sample consumed fewer than 5 servings of fruits and vegetables per day. Consumption of fruits and vegetables was also low in Bangladesh (93\%) (23) and Sri Lanka (82.4\%) (26). In India, 
these figures range from $76 \%$ to $99 \%$ in different states (27). In high-income countries like Qatar, 91\% of the population consumed fewer than 5 servings of fruits and vegetables a day (28). The low consumption of fruits and vegetables might be due to the cultural context as people prefer fatty diets that include foods like samosas, pakoras (fried snack) and sweets. Fruits and vegetables are important for a healthy diet as they provide vitamins, minerals, fibre and phytochemicals. Many studies have shown that an adequate daily intake of fruits and vegetables results in a lower risk of chronic disease, especially heart diseases (29), diabetes and cancers $(30,31)$. Therefore, there is a need to educate the community about the health benefits of eating fruits and vegetables.

\section{Hypertension}

Hypertension was seen in $53 \%$ of our sample; $37 \%$ had stage I hypertension and $15.9 \%$ stage II hypertension, which is higher than reported for India and Bangladesh $(23,27)$. These figures are lower than those reported from Palau, Micronesia region (55\% stage I and $21 \%$ stage II hypertension) (32), and comparable to Malawi (stage I) (32\%) (33) and Nepal (25.7\%) (22). The high prevalence of hypertension is likely related to unhealthy diets and low physical activity as discussed above.

\section{Limitations}

The study was conducted in 2 large provinces of Pakistan (Punjab and Sindh) which are home to $75 \%$ of the Pakistan population. However, the findings cannot be generalized to the other 2 provinces (Khyber Pakhtunkhwa and Baluchistan) or the regions (Federal, Azad Jammu Kasmir, Gilgit Baltistan and Federal Administered Tribal Areas) because of socioeconomic and cultural differences.

\section{Conclusions}

The poor situation of NCD risk factors in Pakistan increasing trends of tobacco consumption, physical inactivity, unhealthy diet, overweight and obesity demands urgent public health interventions. Lack of awareness among the public about NCD risk factors, cheap availability of cigarettes, weak implementation of anti-tobacco laws, and absence of a national NCD policy are some of the key factors responsible for the growing burden of NCDs in the country. Interventions are needed to increase the intake of fruits and vegetables and the amount of exercise taken, especially in youth and young adults, and rigorously implement tobacco control legislation. To control NCDs, different stakeholders, including departments of health, education, sports, environment and media, need to work together to plan more physical activities in educational institutions and raise awareness through media about the importance of a healthy diet in youth and adults.

\section{Acknowledgements}

We acknowledge the technical and financial assistance of WHO and the technical support of Ms Melanie Cowan (WHO headquarters) throughout the survey. We thank Mr Khalid Mahmood for his support in the sample calculation and weighting. We also thank the provincial coordinators: Dr Rizwan Iqbal, Dr Iffat Shabbir, Dr Ayaz Mustafa; the field supervisors: Dr Saira Bashir (deceased), Mr Muhammad Kashif Munir, Mr Shakeel Ahmed Dahar, Mr Allah Rakhia, Dr Faiza Bashir, Ms Sumera Naz and the data collection teams. We acknowledge the efforts of $\mathrm{Mr}$ Mehmood Ahmed, Mr Saeed Ahmed Shahid, Mr Khalid Mehmood, Mr Hafiz Saqib, Mr Zulfiqar Ahmed and Mr Junaid Raza for their assistance in the survey. Last but not least, we sincerely acknowledge the participation of the respondents who voluntarily took part in the study.

Funding: Financial assistance for the survey was provided by the World Health Organization.

Competing interests: None declared.

\section{Prévalence des facteurs de risque pour les maladies non transmissibles chez l'adulte : principaux résultats d'une enquête STEPS au Pakistan}

\section{Résumé}

Contexte: Le Pakistan ne dispose pas de données sur la prévalence des facteurs de risque pour les maladies non transmissibles (MNT) courantes.

Objectifs : La présente étude visait à déterminer la prévalence des facteurs de risque de MNT dans un échantillon de la population des provinces du Penjab et de Sindh.

Méthodes : L'étude a été menée entre 2013 et 2014. Les facteurs de risque des MNT examinés étaient les suivants: tabagisme quotidien, moins de cinq portions de fruits et légumes par jour, activité physique réduite, surcharge pondérale et obésité. Un total de 7710 ménages a été sélectionné et un adulte de chacun d'entre eux a participé à l'étude. Les données ont été recueillies à l'aide de l'outil STEPS de l'OMS (STEP 1 et 2), et analysées conformément au plan statistique mis au point dans le cadre de cette enquête STEPS.

Résultats : La prévalence du tabagisme était de 19,7\%. La majorité des répondants (96,5\%) consommaient moins de cinq fruits et légumes par jour, $41,5 \%$ avaient une activité physique réduite, $26,3 \%$ étaient en surpoids et 14,9\% étaient obèses. La prévalence de l'hypertension de stade 1 et 2, dont les personnes sous traitement médicamenteux, était de $37 \%$ et de $15,9 \%$ respectivement. La prévalence des facteurs de risque pour les MNT différait significativement selon le sexe ( $p=0,0001)$ et la profession ( $p=0,0001)$, ce qui n'était pas le cas pour le groupe d'âge $(p=0,118)$, le niveau d'éducation $(p=0,668)$ et 
la province $(p=0,056)$. Seul $0,6 \%$ de l'échantillon ne présentait aucun de ces cinq facteurs de risque, tandis que $40 \%$ en présentaient entre trois et cinq.

Conclusion : La forte prévalence des facteurs de risque pour les MNT dans les provinces du Penjab et de Sindh, est préoccupante. Des interventions de santé publique sont requises de toute urgence afin de réduire ces facteurs de risque, notamment chez les jeunes et les jeunes adultes.

\section{انتشُّار عوامل الخطر للإِصابة بالأمر اض غير السارية في صفوف البالغين: التتائج الرئيسية المستمدة من مسح (أداة

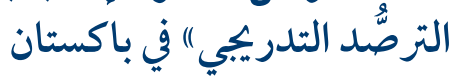

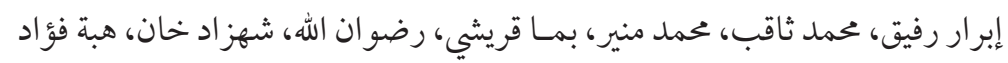
الخلاصة

$$
\text { الخلفية: تفتقر باكستان إلى بيانات بشأن انتشار عوامل خطر الإصابة بالأمر اض غير السارية الشائعة. }
$$

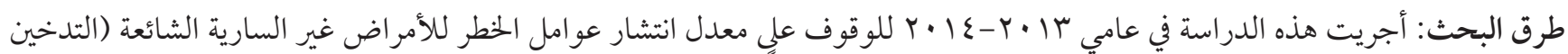

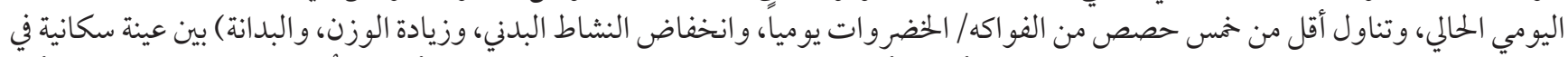

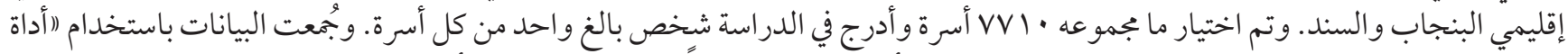

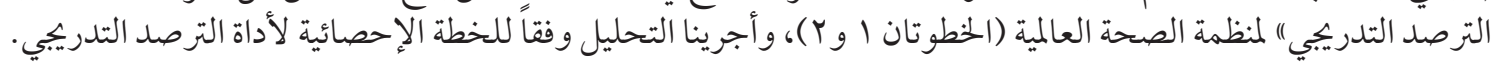

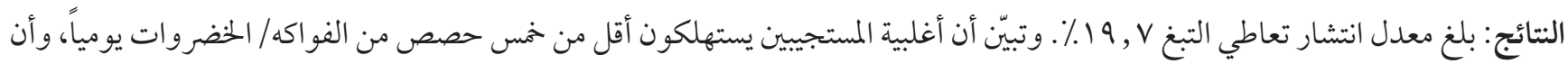

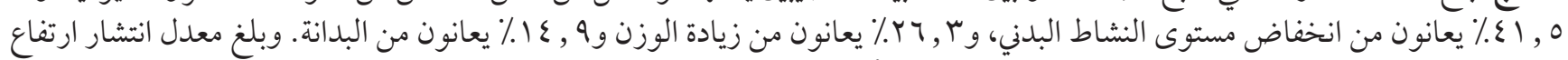

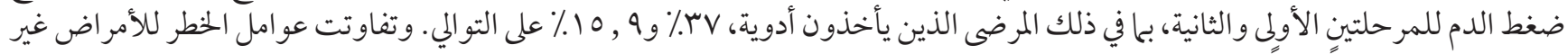

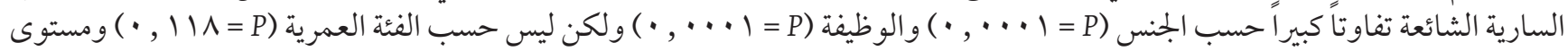

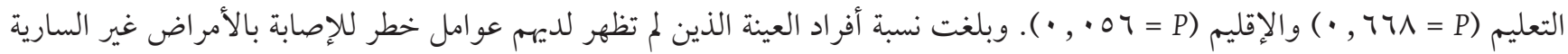

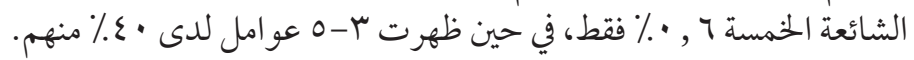

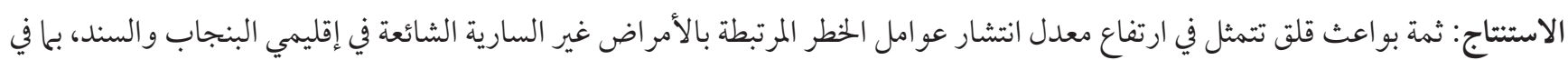

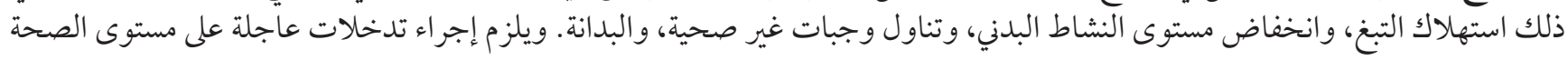
العامة للحد من عوامل الخطر هذه، لا سيا في صفوف النفاط الشباب وصغار ولنار البالغين.

\section{References}

1. World Health Organization. Media centre. Noncommunicable diseases.Fact sheet. Updated June 2017 (www.who.int/mediacentre/factsheets/ fs355/en/, accessed 15 January 2018).

2. Jafar TH, Haaland BA, Rahman A, Razzak JA, Bilger M, Naghavi M, et al. Non-communicable diseases and injuries in Pakistan: strategic priorities.Lancet. 2013 Jun90-2281:(9885)381;29. http://dx.doi.org/10.1016/S7-60646(13)6736-0140 PMID:23684257

3. Lozano R, Naghavi M, Foreman K, Lim S, Shibuya K, Aboyans V, et al. Global and regional mortality from 235 causes of death for 20 age groups in 1990 and 2010: a systematic analysis for the Global Burden of Disease Study 2010. Lancet. 2012 Dec128-2095:(9859)380;15. http://dx.doi. org/10.1016/So-61728(12)6736-0140 PMID:23245604

4. Jafar TH, Levey AS, Jafary FH, White F, Gul A, Rahbar MH, et al. Ethnic subgroup differences in hypertension in Pakistan. J Hypertens. 2003 May;12-905:(5)21. http://dx.doi.org/00014-200305000-00004872/10.1097 PMID:12714864

5. Shera AS, Rafique G, KhwajaI A, Ara J, Baqai S, King H. Pakistan national diabetes survey: prevalence of glucose intolerance and associated factors in Shikarpur, Sindh Province. Diabet Med. 1995 Dec;21-1116:(12)12. PMID:8750223

6. Chronic diseases. In: Pakistan National Health Survey 1994-1990. Islamabad: Federal Bureau of Statistics (Pakistan), Government of Pakistan, National Center for Health Statistics (NCHS), Centers for Disease Control and Prevention (CDC), Pakistan Medical Research Council; 69-1994:49.

7. Khan FS, Lotia-Farrukh I, Khan AJ, Siddiqui ST, Sajun SZ, Malik AA, et al. The burden of non-communicable disease in transition communities in an Asian megacity: baseline findings from a cohort study in Karachi, Pakistan. PLoS One. 2)8;2013):e56008. http://dx.doi.org/10.1371/journal. pone.0056008 PMID:23418493

8. Global status report on noncommunicable diseases 2010. Description of the global burden of NCDs, their risk factors and determinants. Geneva: World Health Organization; 2011.

9. Bonita R, de Courten M, Dwyer T, Jamrozik K, Winkelmann R. Surveillance of risk factors for noncommunicable diseases: The WHO STEPwise approach. Summary.Geneva: World Health Organization; 2001 (www.who.int/ncd_surveillance/media/en/269.pdf, accessed 15 January 2018).

10. Khuwaja AK, Qureshi R, Fatmi Z. Noncommunicable diseases and injuries: action needed in South Asia too. PLoS Med. 2007 Jan;1)4):e38. http:// dx.doi.org/10.1371/journal.pmed.0040038 PMID:17411313

11. Cureau FV, Duarte P, dos Santos DL, Reichert FF. Clustering of risk factors for noncommunicable diseases in Brazilian adolescents: prevalence and correlates.J Phys Act Health. 2014 Jul;9-942:(5)11. http://dx.doi.org/10.1123/jpah.0247-2012 PMID:23676377

12. Bhagyalaxmi A, Atu lT, Shikha J. Prevalence of risk factors of non-communicable diseases in a District of Gujarat, India. J Health Popul Nutr. 2013 Mar;85-78:(1)31. http://dx.doi.org/10.3329/jhpn.v31i1.14752 PMID:23617208 
13. Survey methods. What is Kish selection procedure? (https://surveymethods.com/blog/what-is-the-kish-selection-procedure/, accessed 15 January 2018).

14. World Health Organization. Noncommunicable diseases and their risk factors. STEPS optional modules. (http://www.who.int/chp/steps/ riskfactor/modules/en/, accessed 15 January 2018).

15. Noncommunicable Diseases Risk Factor Survey-Pakistan. Islamabad: Pakistan Health Research Council; 2016.

16. WHO STEPS surveillance manual. World Health Organization; 2017 (www.who.int/ncds/surveillance/steps/STEPS_Manual.pdf?ua=1, accessed 15 January 2018).

17. Provisional summary results of 6th population and housing census-2017. Pakistan Bureau of Statistics; 2017 (www.pbs.gov.pk/content/ provisional-summary-results6-th-population-and-housing-censuso-2017-, accessed 15 January 2018).

18. GATS. Global Adult Tobacco Survey. Fact sheet. Pakistan; 2014 (www.who.int/tobacco/surveillance/survey/gats/pakfactsheet.pdf, accessed 15 January 2018).

19. Saqib MAN, Rafique I, Qureshi H, Munir MA, Bashir R, Arif BW, et al. Burden of tobacco in Pakistan - Findings from Global Adult Tobacco Survey 2014. Nicotine Tob Res. 2017 Aug 18. http://dx.doi.org/10.1093/ntr/ntx179 PMID:29059338

20. Global Adult Tobacco Survey Pakistan. 2014. Islamabad: Pakistan Health Research Council; 2016 (www.who.int/tobacco/surveillance/survey/gats/ pak-report.pdf?ua=1, accessed 15 January 2018).

21. GGYTS. Global Youth Tobacco Survey. Fact sheet. Pakistan; 2013(www.emrowho.int/images/stories/tfi/documents/GYTS_FS_PAK_2013.pdf?ua=1, accessed 15 January 2018).

22. STEPS survey report. Nepal, 2013-2013 (www.who.int/ncds/surveillance/steps/nepal/en/, accessed 15 January 2018).

23. STEPS survey report. Bangladesh, 2013 (www.who.int/ncds/surveillance/steps/bangladesh/en/, accessed 15 January 2018).

24. STEPS survey report. Myanmar, 2009 (www.who.int/ncds/surveillance/steps/myanmar/en/, accessed 15 January 2018).

25. World Health Organization. Global Health Observatory data. Prevalence of insufficient physical activity. Adults aged +18 years (http://www.who. int/gho/ncd/risk_factors/physical_activity_text/en/, accessed 28 January 2018).

26. STEPS survey report. Sri Lanka, 2008 (www.who.int/ncds/surveillance/steps/sri_lanka/en/, accessed 15 January 2018).

27. STEPS survey report. India, 2008-2007 (http://www.who.int/ncds/surveillance/steps/india/en/, accessed 15 January 2018).

28. STEPS survey report. Qatar, 2012 (www.who.int/ncds/surveillance/steps/qatar/en/, accessed 15 January 2018).

29. Rissanen TH, Voutilainen S, Virtanen JK, Venho B, Vanharanta M, Mursu J, et al. Low intake of fruits, berries and vegetables is associated with excess mortality in men: the Kuopio Ischaemic Heart Disease Risk Factor (KIHD) Study. J Nutr. 2003 Jan;204-199:(1)133. PMID:12514290

30. Harding AH, Wareham NJ, Bingham SA, Khaw K, Luben R, Welch A, et al. Plasma vitamin C level, fruit and vegetable consumption, and the risk of new-onset type 2 diabetes mellitus: the European prospective investigation of cancer-Norfolk prospective study. Arch Intern Med. 2008 Jul;9-1493:(14)168. http://dx.doi.org/10.1001/archinte.168.14.1493 PMID:18663161

31. Food, nutrition, physical activity, and the prevention of cancer: a global perspective.Washington (DC): World Cancer Research Fund; 2007.

32. Chiang C, Singeo ST Jr, Yatsuya H, Honjo K, Mita T, Ikerdeu E, et al. Profile of non-communicable disease risk factors among young people in Palau. J Epidemiol. 7-392:(5)25;2015. http://dx.doi.org/10.2188/jea.JE20140156. PMID:25787240

33. STEPS survey report. Malawi, 2012. (www.who.int/ncds/surveillance/steps/malawi/en/, accessed 15 January 2018). 